\title{
New record of Anaticola mergiserrati (Phthiraptera: Ischnocera: Philopteridae) from Sindh Province, Pakistan, with its detailed morpho-taxonomy
}

\author{
Sajid Siyal, Saima Naz*, Ali Murtaza Dharejo and Asma Kanwal Thebo \\ Advanced Parasitology Research Laboratory (APR Lab), Department of Zoology, University of Sindh, Jamshoro- \\ 76080-Pakistan \\ *Corresponding author's email:_dr.symanaz@outlook.com
}

Citation

Sajid Siyal, Saima Naz, Ali Murtaza Dharejo and Asma Kanwal Thebo. New record of Anaticola mergiserrati (Phthiraptera: Ischnocera: Philopteridae) from Sindh Province, Pakistan, with its detailed morpho-taxonomy. Pure and Applied Biology. Vol. 8, Issue 1, pp656-666. http://dx.doi.org/10.19045/bspab.2019.80005

\begin{tabular}{llll}
\hline \hline Received: 08/10/2018 & Revised: 03/01/2019 & Accepted: 07/01/2019 & Online First: 18/01/2019 \\
\hline
\end{tabular}

\section{Abstract}

During the chewing lice examination on ducks for the genus Anaticola Clay, 25 ducks of five species ( 5 birds for each species) were examined from different water bodies of Sindh Province of Pakistan. A total of 65 specimens of chewing lice of genus Anaticola were collected including two species, A. crassicornis (Scopoli, 1773) and A. mergiserrati (De Geer, 1778) from only two species of ducks, common teal Anas crecca (L.) and common pochard Aythya ferina (L.). It is recovered for the first time from a duck of the genus Anas, which make the new host record in the world and first time reported from Pakistan making new country record.

Keywords: Anas; Anaticola mergiserrati; New record; Pakistan; Sindh

\section{Introduction}

Family Anatidae includes the group of water birds like ducks, geese and swans, which are resident as well as migratory birds in Sindh, Pakistan and other parts of the world near natural or artificial water bodies and also grain fields [1-3]. These birds harbor a variety of chewing lice, reported throughout the world, mainly represented by 9 genera of chewing lice [4-9].

The genus Anaticola Clay is specific mainly to the birds of order Anseriformes but also found on flamingoes (order Phoenicopteriformes). It is a large genus with 37 species parasitizing Anatid birds worldwide [5, 9, 10], with more elongated and narrow body. After Clay [10], this genus has been remained contradict in its taxonomical description with in species, however it has been considered as inquirenda and need to explicit its recognized characters [11-15].

Amongst all species of this genus only three species have been found on various bird species of the same subfamily within the family Anatidae, for instance A. anseris (L.), A. mergiserrati (de Geer) and A. crassicornis (Scopoli), A. mergiserrati is known from 16 species, mainly from the tribe Aythyini (subfamily Aythyinae) and tribe Mergini (subfamily Anatinae) but not yet reported from tribe Anatini (subfamily Anatinae) [9, 13, 16-18]. 
In present study, the two species of genus Anaticola were found from a variety of ducks and it was first time that Anaticola mergiserrati was reported from a ducks species of genus Anas. During identification process, it was very difficult to determine the species especially when both closely related species of Anaticola were collected from same bird i.e. Anas crecca and Aythya ferina, hence it was considered a deep necessity to redescribe the present species. Previously from the same region Naz et al., [13] have reported and highlighted the morphotaxonomical characters of A. crassicornis. The morpho-taxonomical features of $A$. mergiserrati are rarely found scattered in the previous literature $[19,20]$ and it was seemed a necessity to elucidate it. Therefore the detailed morpho-taxonomy of this species was needed to be elaborated in present with special reference to the male and female abdominal terminalia and male genitalia, especially when the two species of Anaticola were found together in a host.

\section{Materials and methods}

Total of 25 birds of different ducks of five species, Anas crecca, Anas clypeata, Anas platyrhynchos, Aythya ferina and Aythya fuligula were collected for the examination of their chewing lice mainly for the genus Anaticola from different water bodies of Sindh, Pakistan. Chewing lice were collected from ducks during October 2016 to April 2017, as this is the peak time for the migration of ducks from northern hemisphere to Pakistan.

The methods for collection of chewing lice were followed those of $\mathrm{Naz}$, et al. [13] and Naz [21]. The preservation and slide mounting of the chewing lice specimens was followed as prescribed in literature $[22,23]$. Drawings were made with the aid of a drawing tube attachment Olympus-UDA. For observation of genitalia, ten mature specimens were kept in $10 \% \mathrm{KOH}$ solution in hot water for 8-10 hours and their genitalia were dissected and examined. The specimens then were pinned in micro-vial containing glycerin and deposited at the Museum Collection of Advanced Parasitology Research Laboratory (APR Lab), Department of Zoology, University of Sindh, Jamshoro.

The following parasitological parameters were evaluated: (1) prevalence-the proportion of members of host taxon infested with ectoparasites; (2) intensity-the number of individuals of a chewing lice species on the infested hosts; (3) abundance Range - the minimum and maximum number of individual louse species found on particular host species; (4) Standard Deviation in lice species on both positive hosts.

\section{Results}

Two species of ducks, A. crecca and A. ferina were found infested with two species of the genus Anaticola (Clay) including $A$. crassicornis $(\mathrm{n}=36)$ and $A$. mergiserrati $(n=29)$. Adults and nymphs of these species were found on every birds examined were counted and their individual prevalence, intensity and rate of infestation was calculated (Table 1).

\section{Anaticola mergiserrati (De Geer, 1778)} (Figures 1-12)

(Phthiraptera: Ischnocera: Philopteridae)

Body elongated, narrow and slightly convex at lateral margins; morphometry is given in Table 2).

\section{Head (Figure 3-5)}

Head non-circumfaciate, elongate, triangular, narrowed anteriorly at oculo-temporal region, wider at temples with male $\mathrm{HI}$ : $0.6 \pm 0.8$ and female HI: $0.585 \pm 0.60$.

\section{Preantennal region}

Narrow, longer than broad, rounded and smooth slightly sloped hyaline margin evident with horizontal furrows, marginal carina broken laterally, bearing three pairs of fine antero-lateral marginal setae and one pair of blade like seta present; marginal carinal nodus present; dorsal carina absent; 
pulvinus completed and surrounded with ventral carina.

\section{Antennal region}

Antennae heteromorphic (Figure 5), filiform; scape of male much elongated than female antenna, bearing partially sclerotized texture on it, with three median submarginal fine setae; segment II and III with thumb like lateral process; segment IV short bearing two discoidal sensillae and terminal conical sensillae; conus short and blunt, with anterior seta.

\section{Postantennal region}

As broader as long, slightly narrower at posterior, temples rounded and smooth, temporal marginal carina thin, temporal setae (ts) five small microstate with ts1, 2, 4, 5 microsetae and ts 3 normal seta but short in size; temporal median seta absent;
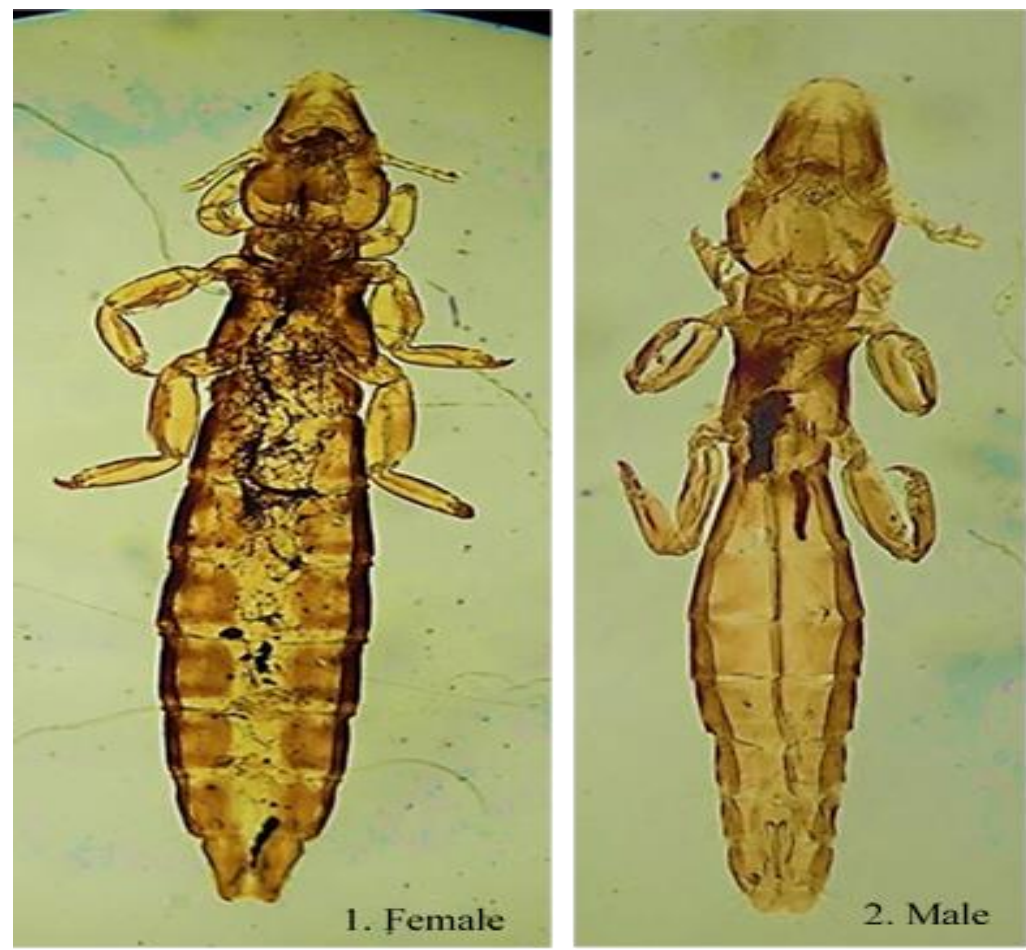

Figures 1-2. Photograph of Anaticola mergiserrati (10×10); 1. Female; 2. Male.

Occipital margin narrow and slightly concave; gular plate elongate, weakly sclerotized, anteriorly merged with mentum.

Table 1. Prevalence, Range, Intensity and male and female ratio of the two species of genus Anaticola recovered from $A$. crecca and $A$. ferina during present study

\begin{tabular}{|c|c|c|c|c|c|c|c|c|c|c|c|}
\hline \multirow{2}{*}{ Host (n) } & \multirow{2}{*}{$\begin{array}{l}\text { Prevalence } \\
(\%)\end{array}$} & \multicolumn{2}{|c|}{ Range } & \multicolumn{2}{|c|}{$\begin{array}{c}\text { Intensity } \\
(\text { Mean } \pm \text { SE) }\end{array}$} & \multicolumn{2}{|c|}{ SD } & \multicolumn{2}{|c|}{$\begin{array}{c}\text { Male: Female } \\
\text { Ratio }\end{array}$} & \multicolumn{2}{|c|}{$\begin{array}{c}\text { Rate of } \\
\text { Infestation }\end{array}$} \\
\hline & & A. $c$.* & A. $m$. & A. $c$. & A. $m$. & A. $c$. & A. $m$. & A. $c$. & A. $m$. & A. $c$. & A. $m$. \\
\hline $\begin{array}{c}\text { Anas crecca } \\
(05)\end{array}$ & 100 & $2-9$ & $1-3$ & $\begin{array}{c}4.6 \pm 1.0 \\
8\end{array}$ & $\begin{array}{c}2 \pm 0.28 \\
2\end{array}$ & 2.416 & 0.632 & 1:0.90 & $1: 2.30$ & \multirow{2}{*}{3.6} & \multirow{2}{*}{2.9} \\
\hline $\begin{array}{c}\text { Aythya ferina } \\
\text { (05) }\end{array}$ & 100 & $1-4$ & $1-5$ & $\begin{array}{c}2.6 \pm 0.5 \\
4\end{array}$ & $\begin{array}{c}3.2 \pm 0.5 \\
93\end{array}$ & 1.222 & 1.326 & $1: 0.85$ & $1: 1.28$ & & \\
\hline
\end{tabular}

*A.c. Anaticola crassicornis; A.m. Anaticola mergiserrati 


\section{Thorax (Figure 6-7)}

Prothoracic and Pterothoracic segments are similar as in A. crassicornis, only the difference is in shoulders of pterothorax are wider in A. mergiserrati than that of $A$. crassicornis. Thoracic legs stout, long as in A. crassicornis; prosternal plate absent; meso-meta sternal plate as in figure 7 , fused, wide, diamond shaped, bearing one pair of seta on anterior edges and one pair of seta at posterior, posterior stalk present.

\begin{abstract}
Abdomen
Same as the abdomen of A. crassicornis, except the size and little setal arrangement (Table 3).

\section{Male Terminalia (Figure 8)}

Dorsal abdominal plate on last segment undivided, complete; anterior tergal plate IX fused with posterior tergum $\mathrm{X}$ and terminal tergal plate XI segment; posterior margin of segment XI chitinized smooth no lobe like thickness found in the specimen.
\end{abstract}

Table 2. Measurement of body parts of the two species of genus Anaticola collected during present study (mean and range in parenthesis)

\begin{tabular}{|c|c|c|c|c|}
\hline \multirow{2}{*}{$\begin{array}{c}\text { Body* } \\
\text { Parts }\end{array}$} & \multicolumn{2}{|c|}{ Anaticola mergiserrati (De Geer, 1773) } & \multicolumn{2}{c|}{ Anaticola crassicornis (Scopoli, 1773) } \\
\cline { 2 - 5 } & Male (n=3) & Female (n=3) & Male (n=3) & Female (n=3) \\
\hline TL & $3.281(2.400-1.763)$ & $4.805(3.466-2.678)$ & $3.200(3.100-3.300)$ & $3.650(3.600-3.700)$ \\
\hline HL & $0.473(0.555-0.391)$ & $0.635(0.644-0.626)$ & $0.725(0.700-0.750)$ & $0.776(0.600-0.770)$ \\
\hline PAW & $0.217(0.200-0.234)$ & $0.248(0.244-0.252)$ & $0.340(0.330-0.350)$ & $0.360(0.340-0.380)$ \\
\hline TW & $0.323(0.333-0.313)$ & $0.375(0.377-0.373)$ & $0.460(0.450-0.470)$ & $0.470(0.450-0.490)$ \\
\hline PL & $0.171(0.177-0.165)$ & $0.186(0.200-0.173)$ & $0.190(0.180-0.200)$ & $0.220(0.210-0.230)$ \\
\hline PW & $0.221(0.200-0.243)$ & $0.291(0.288-0.295)$ & $0.350(0.300-0.400)$ & $0.370(0.360-0.380)$ \\
\hline PtL & $0.370(0.333-0.408)$ & $0.397(0.377-0.417)$ & $0.485(0.480-0.490)$ & $0.520(0.519-0.530)$ \\
\hline PtW & $0.259(0.266-0.243)$ & $0.377(0.355-0.400)$ & $0.480(0.475-0.485)$ & $0.580(0.560-0.600)$ \\
\hline AL & $0.673(1.288-1.330)$ & $1.980(1.760-2.200)$ & $1.800(1.750-1.850)$ & $2.390(2.370-2.410)$ \\
\hline AW & $0.331(0.333-0.330)$ & $0.509(0.533-0.486)$ & $0.632(0.622-0.643)$ & $0.814(0.777-0.852)$ \\
\hline GL & $0.423(0.377-0.470)$ & & $0.650(0.630-0.670)$ & \\
\hline GW & $0.084(0.081-0.088)$ & & $0.105(0.09-0.120$ & - \\
\hline
\end{tabular}

*AL: Abdominal length; AW: Abdominal width; GL: Genital length; GW: Genital width; HL: Head length; PAW: Pre-antennal width; PL: Pronotal length; PtL: Pteronotal length; PtW: Pteronotal width; PW: Pronotal width; TL: Total length; TW: Temporal width. 
Female Terminalia (Figure 10)

Female genital opening ventro-terminal, vulval margin slightly convex and wavy, subgenital plate not deeply concave, with latero-posterior corner without seta; inner margin of vulva bearing a small row of 5-6 marginal microsetae and 8 median microsetae on subgenital plate, terminal segment slightly concave posteriorly.
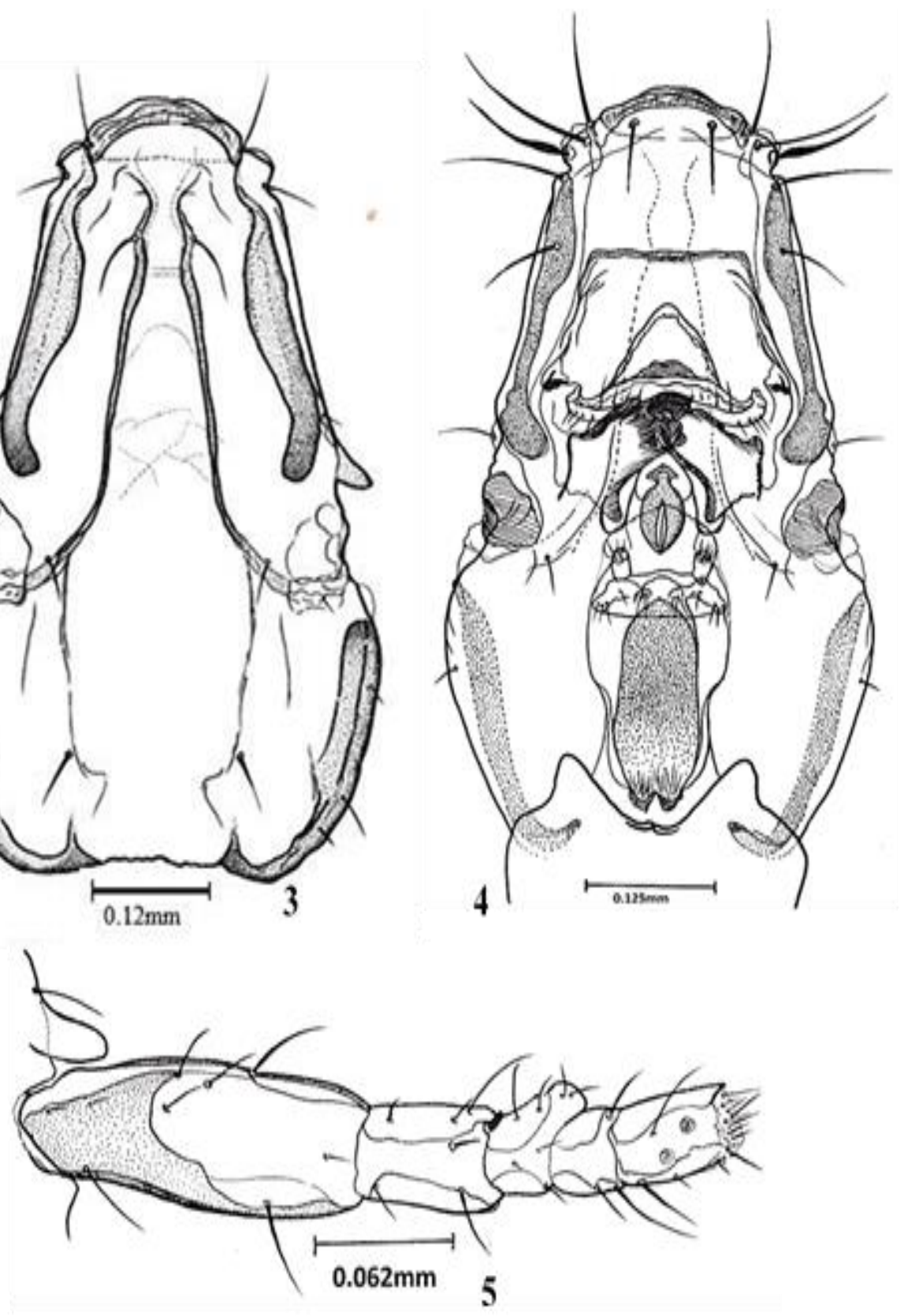

Figures 3-5. Anaticola mergiserrati, 3. Dorsal view of head; 4. Ventral view of head; 5. Details of male Antenna 
Siyal et al.

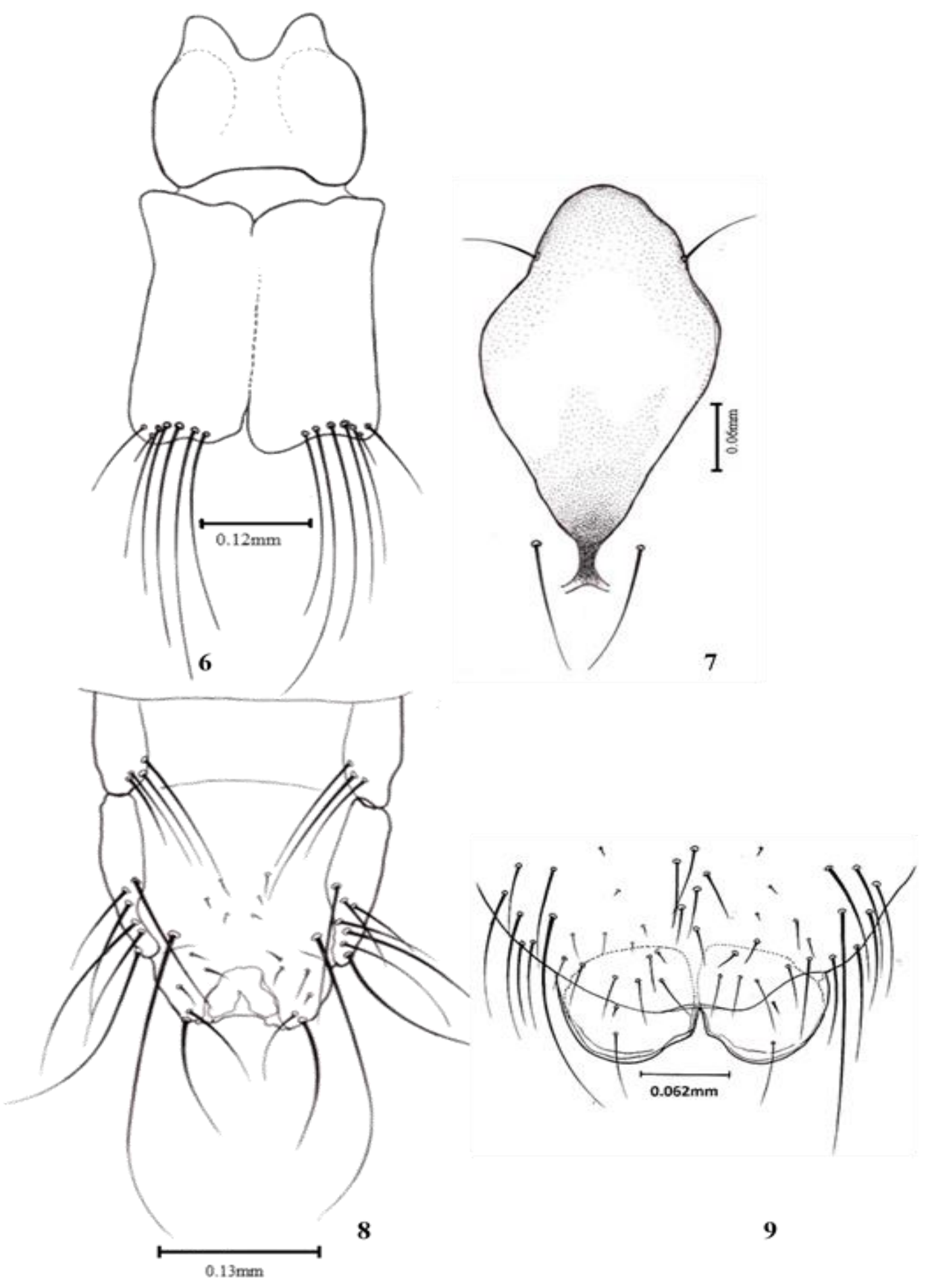

Figures 6-9. Anaticola mergiserrati, 6. Dorsal view of thorax; 7. Meso-metasternal plate; 8. Male terminalia in ventral view; 9. Male terminalia of $A$. crassicornis.

Male Genitalia (Figure 11-12A)

Extending up to abdominal segment III; parameres short and narrow, extending behind up to basal apodeme; mesomeral sclerite elongated, narrow, furnished with two very microsetae on both sides of penis 
and one pair of peg like setae at posterior end; penis typical of generic Y-shaped (Figure 11 and 12A) with anteriorly thick hyaline and posterior end curved ventrally, measuring $0.143-0.147 \mathrm{~mm}$.

\section{Discussion}

The genus Anaticola was first described by Clay [10]; A. crassicornis was designated as the type species for Anas platyrhynchos Linnaeus as its type host. The main diagnostic characters of the genus Anaticola were given by some researchers $[11,19,20]$, but its specific account is not significantly available.

Ducks of different genera and species usually visit the water bodies in the region during winter season and migrate from cold region like Siberia. During their migration, there can be a possibility to carry pathogenic agents with their parasites; keeping this impact in view, ducks were examined for their ectoparasites privy to accurate the outcomes of their parasites that introduce in local region of Sindh water bodies. The present species of chewing louse is noticed under the hypothetical view.

Anaticola mergiserrati was recovered previously from seven genera of ducks including Aythya, Aix, Mergus, Netta, Melanitta, Somateria and Malacorhychus but it has not been reported from genus Anas yet. Anaticola crassicornis was reported from three species of genus Anser but even that has also been previously reported from Anas crecca from Hyderabad, Sindh [17]. In spite of the recovery of $A$. mergiserrati in very early period [24] and found common in ducks and geese species, but its complete characterization and morphology has not been found in details among literature. Due to the close resemblance of male of this species with $A$. crassicornis which was previously described from Pakistan [13], it makes confusion to differentiate in many morpho-taxonomic characteristics especially the preantennal region of head and male genitalia. The morphological differences of both species are given in (Table 3). Therefore, this detailed description of $A$. mergiserrati indeed required to understand the difference of its closet allied species.

Species A. mergiserrati has previously reported from hosts like wood duck (Aix sponsa), redheaded pochard (Aythya americana), white eyed duck (Aythya australis), common pochard (Aythya ferina), tufted duck (Aythya fuligula), greater scaup (Aythya marila), New Zealand scaup (Aythya novaselandiae), ferruginous duck (Aythya nyroca), common merganser (Mergus merganser), red breasted merganser (Mergus serrator), red crested pochard (Netta ruffina), common eider (Somateria mollissima), lesser scaup (Aythya affinis), velvet scoter (Melanitta fusca), pink eared duck (Malacorhynchus membranaceus) [9]; however it was first time recovered from common teal (Anas crecca), making a new host on record.

In the Indo-Pakistan region, A. crassicornis was first reported from Lyallpur (present-day Faisalabad, Pakistan), Kulu and the Himalayan regions (present-day India) on Tadorna ferruginea Pallas, collected in 1932, Anas crecca Linnaeus in 1933 and Aythya ferina Linnaeus in 1939, and reported by Ansari [25], however, his report only took superficial characteristics into account; whereas, $A$. mergiserrati has not been reported from the region prior to the preset study and put new country on record $[26,27]$. Among other Philopterid lice found on ducks and geese, it was also observed that specimens of genus Anaticola were always found in higher abundance as compared to Anatoecus species. It was also reported by Naz et al. [13, 17], Garbarino et al. [28], which revealed that Anaticola species are more prevalent in the ducks at present region. 
Siyal et al.
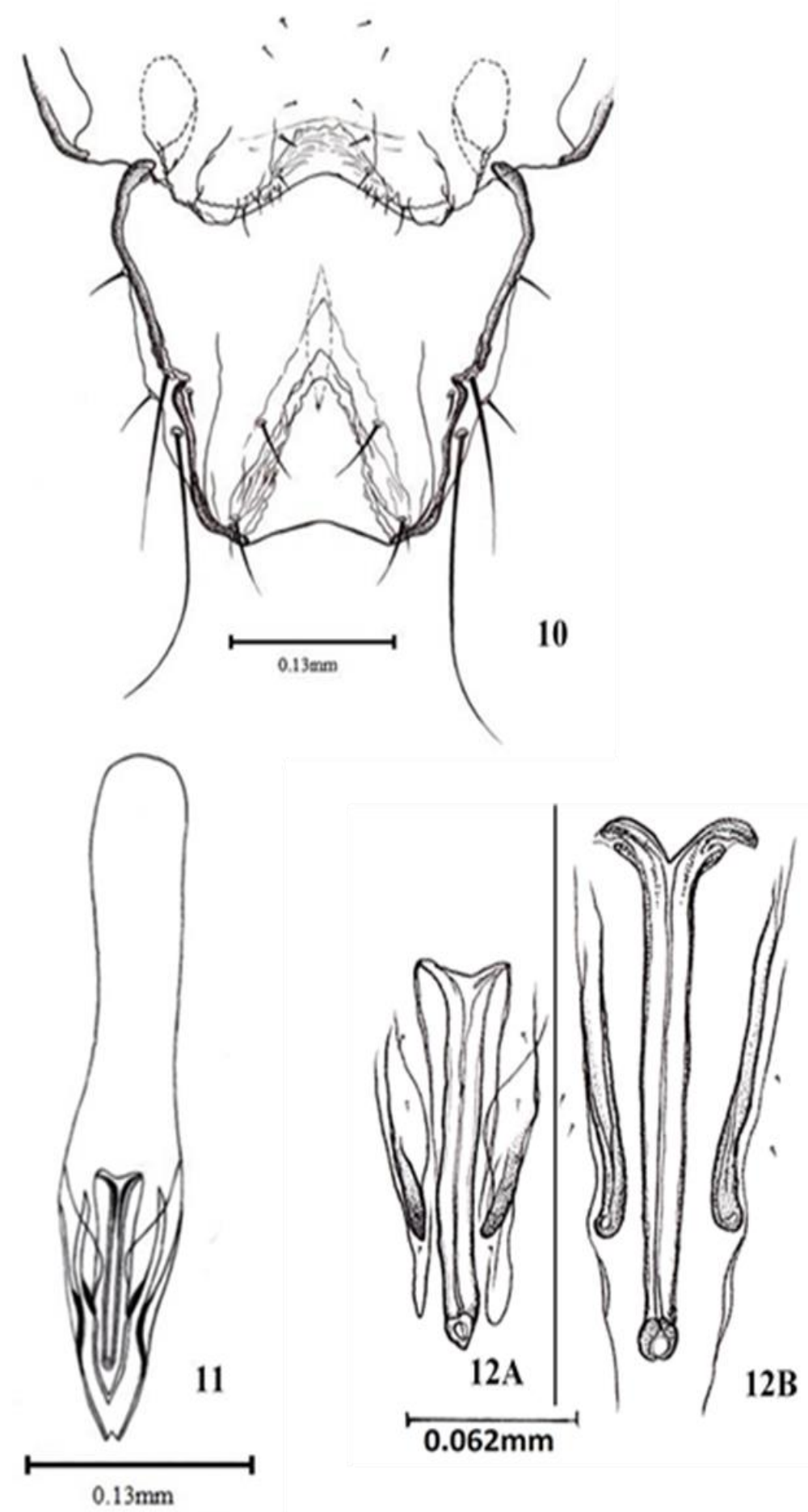

Figures 10-12(A,B). Anaticola mergiserrati, 10. Female terminalia in ventral view; 11. Male genitalia complete armature; 12. Mesomeral sclerite and penis details of $A$. mergiserrati (A), A. crassicornis (B). 
Table 3. Morphological differences between A. crassicornis and A. mergiserrati, collected from same hosts during present study

\begin{tabular}{|c|c|c|}
\hline Characters & A. crassicornis & A. mergiserrati \\
\hline Head & $\begin{array}{l}\text { Head non-circumfasciate, elongate, } \\
\text { triangular, narrow anteriorly and wide at } \\
\text { temporal region. } \\
\text { Temples rounded and smooth. } \\
\text { Hyaline margin present, marginal carina } \\
\text { broken laterally. } \\
\text { Marginal carinal nodus absent; dorsal } \\
\text { carina absent. } \\
\text { Anterior marginal carinal setae short, fine, } \\
\text { not spike or blade like seta seen. } \\
\text { Antennae heteromorphic, scape slightly } \\
\text { narrower measuring } 0.18 \mathrm{~mm} \text {, } \\
\text { sclerotization not visible in any specimen, } \\
\text { one -two median setae present, segment } \\
\text { III with slightly curved short process. }\end{array}$ & $\begin{array}{l}\text { Head non-circumfasciate, elongate, } \\
\text { triangular, narrow anteriorly and wide at } \\
\text { oculo-temporal region. } \\
\text { Temples rounded and smooth slightly } \\
\text { sloped. } \\
\text { Hyaline margin present and evident, } \\
\text { marginal carina broken laterally. } \\
\text { Marginal carina nodus present; dorsal } \\
\text { carina absent. } \\
\text { Anterior marginal carinal setae short, } \\
\text { fine, one pair of spike or blade like setae } \\
\text { present. } \\
\text { Antennae heteromorphic, scape shorter } \\
\text { than A. crassicornis (0.159 mm), half } \\
\text { sclerotized bearing three median } \\
\text { subterminal fine setae, segment III with } \\
\text { blunt short process (Figure 5). }\end{array}$ \\
\hline $\begin{array}{c}\text { Meso-sternal } \\
\text { plate }\end{array}$ & $\begin{array}{l}\text { Meso-metasternal plate very weak; two } \\
\text { pairs of microsetae present on the anterior } \\
\text { and posterior margins of the meso- } \\
\text { metasternal plate. }\end{array}$ & $\begin{array}{l}\text { Meso-meta sternal plate fused, wide, } \\
\text { diamond shaped, bearing one pair of } \\
\text { seta on anterior edges and one pair of } \\
\text { seta at posterior (Figure } 7 \text { ). }\end{array}$ \\
\hline Thorax & $\begin{array}{l}\text { Prothorax short and Pterothorax long and } \\
\text { narrow. } \\
\text { Pterothorax slightly partially divided at } \\
\text { posterior margin. }\end{array}$ & $\begin{array}{l}\text { Prothoracic and Pterothoracic segment } \\
\text { are similar as in A. crassicornis. Only } \\
\text { the difference is shoulders of } \\
\text { pterothorax are wider in } A \text {. mergiserrati } \\
\text { than that of } A \text {. crassicornis }\end{array}$ \\
\hline Abdo & $\begin{array}{l}\text { Comparatively wider, oblong to elongate. } \\
\text { Pleurites thin and less sclerotized; } \\
\text { subgenital plate of female wide and long, } \\
\text { deeply concave at median, bearing } 6 \text { pairs } \\
\text { long fine setae and } 2 \text { pairs microsetae at } \\
\text { posterior vulval margin. Male terminalia } \\
\text { chaetotaxy as in Figure } 9 .\end{array}$ & $\begin{array}{l}\text { Narrower, elongated, slender. } \\
\text { Pleurites thick and sclerotized; } \\
\text { subgenital plate wide and short, } \\
\text { shallowly concave, bearing } 5 \text { pairs of } \\
\text { short spinous setae with large alveoli at } \\
\text { vulval margin. } \\
\text { Male terminalia chaetotaxy as in Figure } \\
8 .\end{array}$ \\
\hline Genitalia & $\begin{array}{l}\text { Extending up to abdominal segment IV. } \\
\text { Parameres short and narrow. Mesomere } \\
\text { long, relatively wider, bearing two peg like } \\
\text { setae, penis Y-shaped anteriorly thick with } \\
\text { clearly bifurcated anterior end and } \\
\text { posteriorly slightly curved, measuring } \\
0.223-0.244 \mathrm{~mm} \text {. Lateral sclerites of } \\
\text { endomere weak or absent (Figure 12B). }\end{array}$ & $\begin{array}{l}\text { Extending up to abdominal segment III. } \\
\text { Longer than the genitalia of } A \text {. } \\
\text { crassicornis. Parameres long and } \\
\text { narrow, extending behind basal } \\
\text { apodeme. Mesomeral sclerite short and } \\
\text { narrow; penis Y-shaped with anteriorly } \\
\text { short bifurcation and thin and posterior } \\
\text { end prominently curved, measuring } \\
0.143-0.147 \mathrm{~mm} \text { (Figure 12A). }\end{array}$ \\
\hline
\end{tabular}




\section{Authors' contributions}

Conceived and designed the experiments: $\mathrm{S}$ Siyal \& S Naz, Performed the experiments: S Siyal \& S Naz, Analyzed the data: S Siyal \& AK Thebo, Contributed reagents/ materials/ analysis tools: S Siyal \& AK Thebo, Wrote the paper: S Siyal, S Naz \& AM Dharejo.

\section{Acknowledgment}

The authors are in debt to acknowledge the Higher Education Commission (HEC) Islamabad, Pakistan to provide financial aid under National Research Program for Universities (NRPU) with Project No. 204514/14. Also to acknowledge the authority of Sindh Wildlife Department for allowing the authors to collect host birds.

\section{References}

1. Roberts TJ (1991). The Birds of Pakistan. Vol 1. Non-Passeriformes. Oxford Uni. Press. Oxford. ISBN, 0-1955740-4.

2. Sonobe K \& Usui SA (1993). Field Guide to the Water birds of Asia, Wild Bird Society of Japan, Tokyo.

3. Grimmett R, Inskipp C \& Inskipp T (1998). Birds of the Indian subcontinent. Delhi Oxford University Press. India. ISBN: 0-1956-4907-9.

4. Hopkins GHE \& Clay T (1952). A check list of the genera and species of Mallophaga. The British Museum (Natural History), London. www.phthiraptera.info.

5. Keler SV (1960). Über die dualistische Differenzierung der Gattung Anatoecus Cummings (Mallophaga). Zeitschriftfür Parasitenkunde 20: 207-316.

6. Price RD \& Beer JR (1965). The Colpocephalum (Mallophaga:

Menoponidae) of the

Ciconiiformes. Ann Entomol Soc Am 58: 111-131.

7. Price RD (1971). A review of genus Holomenopon (Mallophaga; Menoponidae) from Anseriformes. Ann Ento Soc 43(4): 372-377.
8. Emerson KC (1972). Checklist of the Mallophaga of North America (North of Mexico), Part I-IV, birds host list; Desert Test Centre, Dugway, Utah; 1-216.

9. Price RD, Hellenthal RA, Palma RL, Johnson KP \& Clayton DH (2003).The Chewing Lice: World Checklist and Biological Overview. Champaign, IL, USA: Illinois Natural History Survey Special Publication.

10. Clay $T$ (1936).Two new genera of Mallophaga. Proc Zool Soc Lond 615618.

11. Eichler W \& Vasjukova TT (1980). Die Mallophagen gattung Anaticola (Phthiraptera, Mallophaga). Deutsche Entomol Zeitschrift 27: 335-375.

12. Ledger JA (1980). The arthropod parasites of vertebrates in Africa south of the Sahara. Phthiraptera (Insecta). Publ of the S African Inst Med Res 4: 1-327.

13. Naz S, Rizvi SA \& Sychra O (2010). First record of Anaticola crassicornis (Scopoli, 1763) of goose from Sindh, Pakistan. Zootaxa 2693: 60-66.

14. Dik B \& Uslu U (2012). Studies on chewing lice (Phthiraptera) species found on some duck (Anseriformes: Anatidae) species at lake Akşehir, Turkey. Kafkas Univ Vet Fak Der 18: 1055-1060.

15. Ahmed A, Gupta N, Saxena AK \& Gupta DK (2015). Population levels of Phthiraptera on domestic ducks (Anas platyrhynchos) (Anseriformes: Anatidae). $J$ Parasitic Dis DOI: 10.1007/s1263a-013-0398-Y.

16. Castresana L, Martin N \& Mateo, M (1999). Study of the ectoparasitic mallophaga of Anatidae (Insecta, Mallophaga) in the Iberian Peninsula. Identification, biometric characteristics and biological aspects. Zoologica Baetica 10: 6386.

17. Naz S, Rajper AA \& Chandio AH (2016). New Records of some 
Phthiraptera Chewing lice of birds from urban areas of Hyderabad Sindh, Pakistan. Punjab Uni J Zoo 31(2): 193201.

18. Kumar V, Shamimul H, Saxena KA, Arya G \& Ahmed Z (2014). Population levels of Phthiraptera on Graylag Goose, Anser anser(L.). Turkish J Parasitol 37(4): 273-276.

19. Clay T \& Hopkins GHE (1954). The early literature of Mallophaga. Part III, 1776-1786. Bull British Mus (Nat Hist) Entomol 3: 221-266.

20. Zlotorzycka J (1980). The keys to the Insects of Poland. Chewing lice Mallophaga, part 6, Superfamily Philopteroidea, families: Meinertzhageniellidae, Lipeuridae, Degeeriellidae, Pseudonirmidae, Giebeliidae, Esthiopteridae and Acidoproctidae Panstwowe Wydawnic two Naukowe, Warsaw, 200.

21. Naz S (2008). Studies on the Mallophagan insects, attacking birds of Karachi. Ph.D. Thesis. Deptt. of Zoo Univ, Karachi.

22. Dalgleish RC (1966). An improved technique for collecting bird ectoparasites. Turtox News 44: 75.
23. Lakshminarayana KV (1986). Data book for the study of chewing lice (Phthiraptera: Insecta). Rec Zool Surv India, Miscel Pub Occasional papers No. 81: 1-63.

24. De Geer C (1778). Memories pour server a Phistorie de Insectes, Stockholm.

25. Ansari MAR (1947). Mallophaga (Ischnocera) infesting birds in the Punjab (India). Proc Nat'l Inst Sci India 13: 253-303.

26. Dik B (2010). New records of chewing lice (Phthiraptera) from some bird species in Turkey. Turkey Parasitol Derg 34: 168-173.

27. Dik B, Hugul F \& Ceylon O (2017). Chewing lice (Phthiraptera: Amblycera, Ischnocera) of some aquatic birds in Konya province, Turkey, new records for Turkish fauna. Ankara Univ Vet Fak Derg. 64: 307-312.

28. Garbarino VR, Campbell JW, O'Brein J, Proctor HC \& Dik B (2013). Phthiraptera and Acari collected from 13 species of Waterfowl from Alabama and Georgia. Southeastern Naturalist 12(2): 413-426. 